\title{
(2) OPEN ACCESS \\ Effects of military life on changes in body mass index of enlisted men: a cross-sectional study
}

\author{
Bb Ni Lee, ${ }^{1}$ SW Bae (0), 'S Y Oh, ${ }^{1}$ J H Yoon, ${ }^{2}$ J Roh, ${ }^{2}$ J U Won ${ }^{2}$
}

- Additional material is published online only. To view please visit the journal online (http://dx.doi.org/10.1136/ bmjmilitary-2019-001401).

${ }^{1}$ Department of Public Health, Graduate School, Yonsei University, Seodaemun-gu, Seoul, The Republic of Korea ${ }^{2}$ Department of Preventive Medicine, Yonsei University College of Medicine, Seodaemun-gu, Seoul, The Republic of Korea

\section{Correspondence to} Dr J U Won, Department of Preventive Medicine, Yonsei University College of Medicine, Seodaemun-gu, Seoul, The Republic of Korea; juwon@ yuhs.ac

BNL and SWB contributed equally.

Received 9 January 2020 Revised 2 April 2020 Accepted 2 April 2020
A) Check for updates

(c) Author(s) (or their employer(s)) 2020. Re-use permitted under CC BY-NC. No commercial re-use. See rights and permissions. Published by BMJ.

To cite: Lee BN, Bae SW Oh SY, et al. BMJ Mil Health Epub ahead of print: [please include Day Month Year]. doi:10.1136/

bmimilitary-2019-001401

\section{ABSTRACT}

Background Obesity is a serious health problem with an incidence that is increasing rapidly. Enlisted men are a distinctive group characterised by 24-hour communityliving and are likely to experience changes in body weight as a result of regular diet and exercise during enlistment. Methods This study reviewed data from the Second Military Health Survey. Changes in body mass index (BMI) before and during military service were analysed using paired t-test. We calculated OR and $95 \% \mathrm{Cl}$ for factors affecting weight improvement during military service through logistic regression.

Results The mean BMI in the underweight group increased by $5.87 \mathrm{~kg} / \mathrm{m}^{2}$ during service, while that in the normal weight group increased by $1.18 \mathrm{~kg} / \mathrm{m}^{2}$. In contrast, the mean BMI in the overweight group decreased by $5.47 \mathrm{~kg} / \mathrm{m}^{2}$ during service. The OR for an improved BMI in the subjective good health group compared with the subjective poor health group was statistically significant ( $O R=1.71,95 \% \mathrm{Cl} 1.02$ to 2.87). The OR for an improved BMI was significantly higher in the group with three or more times per week of strength training than in the group with one to two times per week of strength training, and was higher among the marines compared with the Army soldiers $(\mathrm{OR}=1.48,95 \% \mathrm{Cl} 1.03$ to 2.12 and $\mathrm{OR}=2.15$, $95 \%$ Cl 1.07 to 4.32 , respectively).

Conclusions Strength training showed a statistically significant increase in BMI during military service. Furthermore, the BMI of men who were underweight before their service increased, while it decreased among those who were overweight.

\section{INTRODUCTION}

According to the WHO, the number of obese (body mass index $(\mathrm{BMI}) \geq 30 \mathrm{~kg} / \mathrm{m}^{2}$ ) people worldwide has tripled since 1975, and as of 2016, 39\% of adults are overweight (BMI $\geq 25 \mathrm{~kg} / \mathrm{m}^{2}$ ) or obese. ${ }^{1}$ Excess body fat impairs health and increases the risk of mortality and morbidity such as cardiovascular disease, diabetes mellitus, hypertension, musculoskeletal disorders and cancer. ${ }^{2-7}$ Obesity is a serious health problem, and its incidence has been increasing rapidly not only in Western countries, but also in many Asian countries, including South Korea ${ }^{8-11}$ Although the rate of obesity in South Korea is lower than that in any other country of the Organisation for Economic Co-operation and Development, it has increased in recent years. ${ }^{12-14}$ In particular, the number of overweight or obese Korean men has been increasing rapidly. ${ }^{75-17}$

South Korean men are required by the Military Service Act to undergo draft physical examination in the year they turn 19 years old. ${ }^{18}$ They must also

\section{Key messages}

The number of overweight or obese Korean men has been increasing rapidly.

- Most men are required to go through military service in their early 20 s and this is an important shared experience for them.

- Enlisted men are a distinctive group characterised by 24-hour community life.

- They are likely to experience changes in body weight as a result of regular diet and exercise during enlistment.

- Regular diet and exercise during military service improved enlisted men's body mass index.

serve in the military for approximately two years during a certain period. ${ }^{19}$ Men are required to go through military service in their early 20 s and this is an important shared experience for them. ${ }^{20}$

Previous studies in adolescents and adults have shown that obesity is related to factors such as sex, age, race, eating habits, smoking, physical activity, sleep duration, stress and depression. ${ }^{21-26}$ Enlisted men are a distinctive group characterised by 24-hour community life. ${ }^{20}$ They are likely to experience changes in body weight as a result of regular diet and exercise during enlistment. However, studies on obesity among enlisted Korean soldiers are scarce; domestic studies have been conducted mainly on military officers. ${ }^{7}$

This study aimed to analyse changes in BMI of enlisted men before and during military service and to investigate the effects of military life, with its regular diet and exercise, on BMI. Our principal conclusion is that BMI improves to normal during military service, irrespective of whether the individual participant was overweight or underweight before service.

\section{MATERIALS AND METHODS}

Study design and participants

This study reviewed data from the Second Military Health Survey (2015) after obtaining approval from the School of Military Medicine in South Korea. ${ }^{27-30}$ The Second Military Health Survey included a final sample of 2500 officers and enlisted men in the Army, Navy, Marine Corps and Air Force after stratification for class, branch of military service and regional distribution using a questionnaire from July to August 2015. The response rate was $100.0 \%$ as all officers and enlisted soldiers completed the survey. This study used the data collected from the Army, Navy, Marine Corps and Air Force enlisted 
Table 1 Changes in BMI before and during military service according to general characteristics

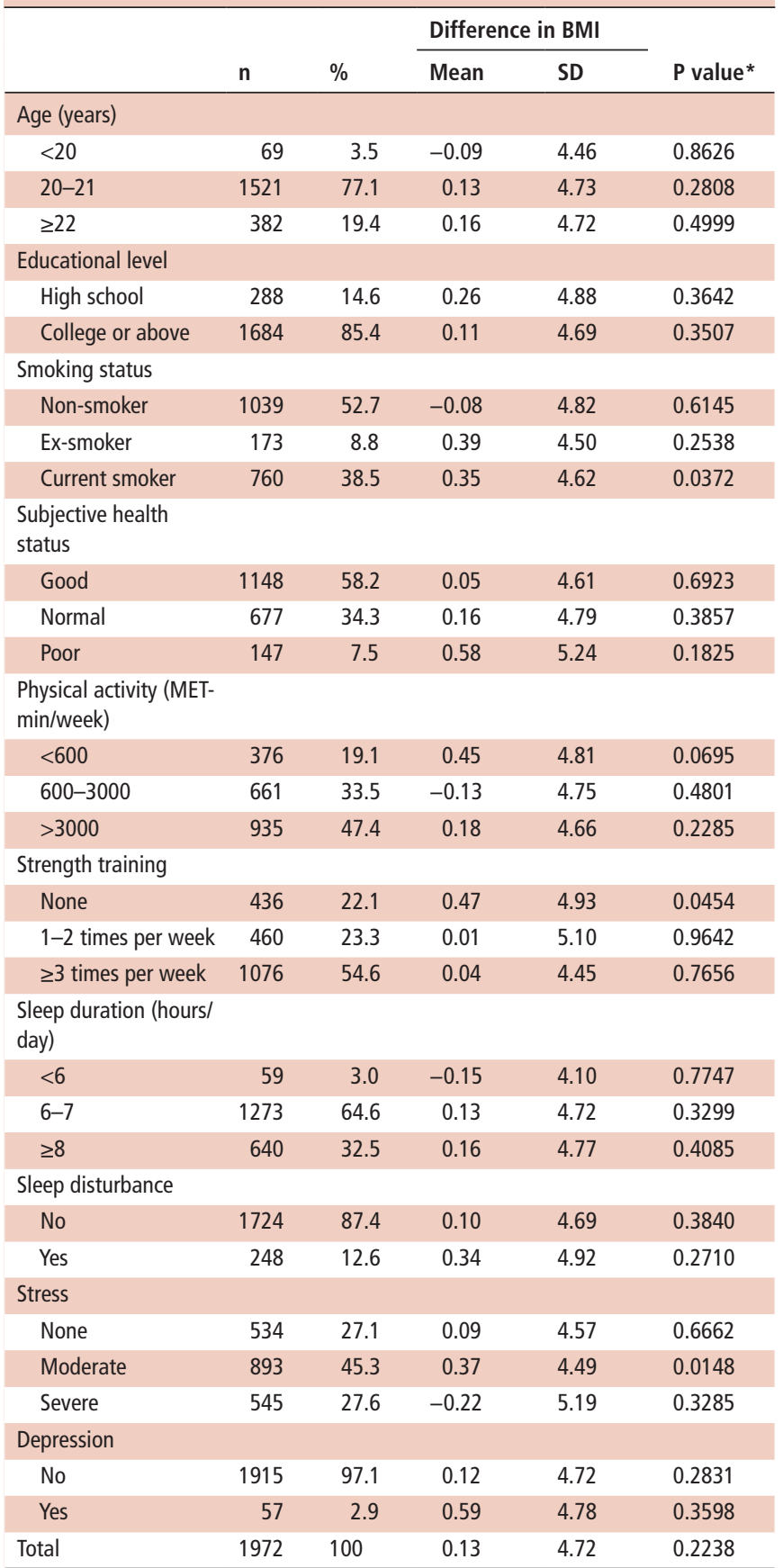

${ }^{*}$ Analyses were performed using paired t-test.

BMI, body mass index; MET, metabolic equivalent of task.

men performing mandatory military service. After the exclusion of 520 officers and eight enlisted men who provided incomplete responses, 1972 were included in the final analysis. In addition, to compare BMI before and during military service for each participant, data on BMI before service were collected from the Military Entrance Physical Examination database conducted on the day of enlistment, after obtaining approval from the Republic of Korea Army Headquarters Personnel Administration. 'During military service' was defined as the time of response to the survey.

\section{Main outcome variables}

Changes in BMI were determined by calculating the difference in BMI (BMI during military service - BMI before military service) for each participant. Participants with BMI $<18.5 \mathrm{~kg} / \mathrm{m}^{2}$ were classified as underweight, those with BMI $18.5-24.9 \mathrm{~kg} / \mathrm{m}^{2}$ were classified as normal weight, and those with BMI $\geq 25 \mathrm{~kg} /$ $\mathrm{m}^{2}$ were classified as overweight. Change in BMI was analysed according to whether the participant's weight during service was maintained, improved or deteriorated compared with the weight before service. Weight was considered maintained if the weight during military service was unchanged compared with the weight before service. Weight was considered to have improved if an individual who was underweight or overweight before service had normal weight during service. Weight was considered to have deteriorated if an individual with normal weight before service became either underweight or overweight during service, or if someone underweight before service became overweight, or if someone overweight became underweight during service.

\section{Covariates}

Because the participants in this study were all male, the variable sex was excluded from the general characteristics. Age was divided into three categories: $<20,20-21$ and $\geq 22$ years. Educational level was divided into high school graduates and college graduates or above. Smoking status was classified into non-smoker, ex-smoker and current smoker. Subjective health status was rated according to responses on a 5-point Likert scale: very good, good, normal, poor and very poor. Responses of 'very good' and 'good' were grouped together as 'good', and responses of 'poor' and 'very poor' were grouped together as 'poor'.

Physical activity was measured using the International Physical Activity Questionnaires and was based on the metabolic equivalent of task (MET). The physical activity variable was calculated as MET-min/week scores. Total physical activity was divided into those who did not exercise except for activities of daily life (METs <600), those who exercised some $(600 \leq$ METs $\leq 3000)$ and those who exercised more to promote health (METs $>3000)$. $^{3132}$

Strength training was not scored as MET in the questionnaire domain was related to physical activity. Strength training was used as a separate variable and classified as none, one to two times per week, and three or more times per week based on participants' responses to the number of days they performed the training.

Sleep duration was divided into three categories: less than six hours, six to seven hours, and eight or morehours. Sleep disturbance was rated according to three items (having difficulty falling asleep, difficulty staying asleep and lack of sleep due to waking up too early) using a 5-point Likert scale. Responses of 'slightly severe' and 'very severe' were grouped together as having sleep disturbance, whereas other responses were grouped as having no sleep disturbance.

Military characteristics were classified according to the branch participants served in (Army, Navy, Marine Corps or Air Force) and were further divided into combat branch, technical branch and administrative/special branch. Service period was divided into four categories: $<6,6-11,12-17$ and $\geq 18$ months. The types of workplace were divided into large, middle and small cities; 'gun' (country), 'eup' (town) and 'myeon' (township); and remote areas. Working hours were classified into $<40$ hours, $40-55$ hours and $\geq 56$ hours.

\section{Statistical analyses}

The general and military characteristics of the participants were analysed using frequency analysis. Changes in BMI before and during military service were analysed using paired t-test. 
Table 2 Improvements in body weight during military service according to general characteristics

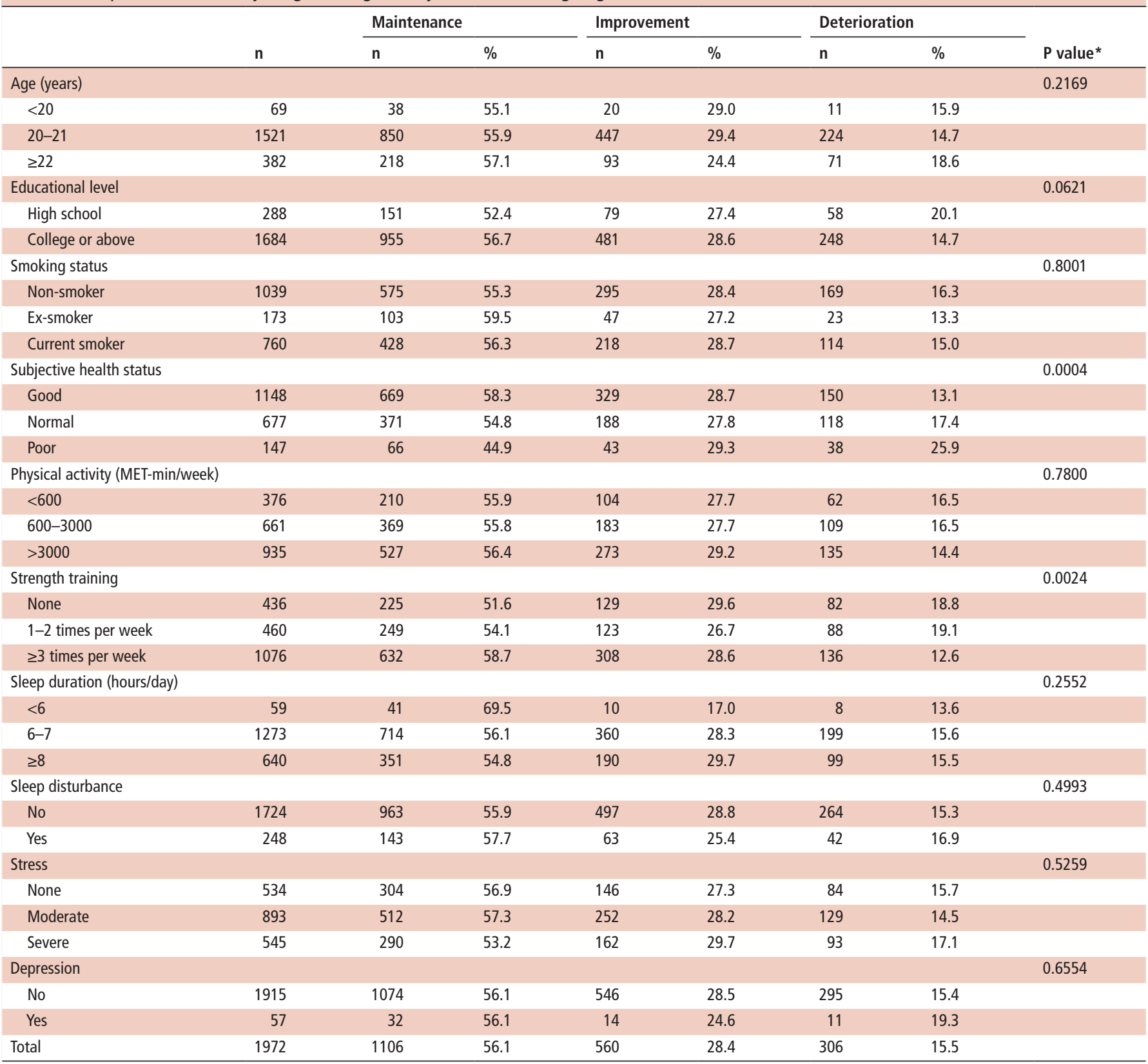

*Analyses were performed using $\chi^{2}$ test.

MET, metabolic equivalent of task.

Changes in weight before and during military service were divided into maintenance, improvement and deterioration and were analysed using the $\chi^{2}$ test. Fisher's exact test was performed when an expected frequency was $<5$. To identify the factors affecting improvements in BMI, we performed a logistic regression analysis after excluding the maintenance group and setting the deterioration group as the reference group, and then calculated the OR and 95\% CI. We considered values of $p<0.05$ as

Table 3 Changes in BMI before and during military service according to the weight group before military service

\begin{tabular}{|c|c|c|c|c|c|c|c|c|}
\hline \multirow{2}{*}{$\begin{array}{l}\text { Weight group before } \\
\text { military service }\end{array}$} & \multirow[b]{2}{*}{$\mathrm{n}$} & \multicolumn{2}{|c|}{ BMI before service, $\mathrm{kg} / \mathrm{m}^{2}$} & \multicolumn{2}{|c|}{ BMI during service, $\mathrm{kg} / \mathrm{m}^{2}$} & \multicolumn{2}{|c|}{ Difference in BMI } & \multirow[b]{2}{*}{ P value* } \\
\hline & & Mean & SD & Mean & SD & Mean & SD & \\
\hline Underweight & 230 & 17.49 & 0.70 & 23.36 & 2.76 & 5.87 & 2.85 & $<0.0001$ \\
\hline Normal & 1269 & 21.64 & 1.76 & 22.82 & 2.63 & 1.18 & 3.12 & $<0.0001$ \\
\hline Overweight & 473 & 28.18 & 2.70 & 22.71 & 2.50 & -5.47 & 3.55 & $<0.0001$ \\
\hline Total & 1972 & 22.72 & 3.86 & 22.85 & 2.62 & 0.13 & 4.72 & 0.2238 \\
\hline
\end{tabular}

${ }^{*}$ Analyses were performed using paired t-test.

BMI, body mass index. 
Table 4 Improvements in body weight during military service according to weight group before military service

\begin{tabular}{|c|c|c|c|c|c|c|c|c|}
\hline \multirow{2}{*}{$\begin{array}{l}\text { Weight group before } \\
\text { military service }\end{array}$} & \multirow[b]{2}{*}{$\mathrm{n}$} & \multicolumn{2}{|c|}{ Maintenance } & \multicolumn{2}{|c|}{ Improvement } & \multicolumn{2}{|c|}{ Deterioration } & \multirow[b]{2}{*}{$P$ value } \\
\hline & & $\mathrm{n}$ & $\%$ & $n$ & $\%$ & $n$ & $\%$ & \\
\hline Underweight & 230 & 4 & 1.7 & 171 & 74.4 & 55 & 23.9 & $<0.0001^{*}$ \\
\hline Overweight & 473 & 76 & 16.1 & 389 & 82.2 & 8 & 1.7 & \\
\hline Total & 1972 & 1106 & 56.1 & 560 & 28.4 & 306 & 15.5 & \\
\hline
\end{tabular}

${ }^{*}$ Analyses were performed using Fisher's exact test.

statistically significant. All analyses were performed using SAS V.9.4 software.

\section{RESULTS}

A high proportion of participants were aged 20-21 years (1521 or $77.1 \%$ of all participants). A high proportion also reported that they were non-smokers, their perceived health was good, they performed strength training three or more times per week, and their stress level was moderate.

From before military service to during, BMI in smokers increased by $0.35 \mathrm{~kg} / \mathrm{m}^{2}$, which is statistically significant $(p=0.0372)$. Similarly, BMI increased by $0.47 \mathrm{~kg} / \mathrm{m}^{2}(\mathrm{p}=0.0454)$ in those reporting no strength training and by $0.37 \mathrm{~kg} / \mathrm{m}^{2}$ $(\mathrm{p}=0.0148)$ in those whose perceived stress level was moderate (Table 1).

Changes in body weight during military service are shown in Table 2. Of the participants, $28.4 \%$ improved in weight, which is a much higher proportion than those whose weight deteriorated (15.5\%). Among those who perceived their health status as poor, the proportion of those with deteriorated health status was higher than those with maintained health status $(p=0.0004)$. Among those who reported performing strength training three or more times per week, the proportion of those with maintained health status was higher than those with deteriorated health status $(p=0.0024)$.

On grouping the participants according to BMI before military service, BMI in the underweight group increased during military service, whereas that in the overweight group decreased, showing that BMI returned to normal ranges during military service (Table 3). The mean BMI in the underweight group increased by $5.87 \mathrm{~kg} / \mathrm{m}^{2}$ during service, while that in the normal weight group increased by $1.18 \mathrm{~kg} / \mathrm{m}^{2}$. In contrast, the mean BMI in the overweight group decreased by $5.47 \mathrm{~kg} / \mathrm{m}^{2}$ during service. There was a statistically significant change in BMI in all groups $(\mathrm{p}<0.0001)$.

In the underweight group, most participants had an improvement in weight $(171,74.4 \%)$ during military service. In the normal weight group, most participants maintained their weight. Similarly, most participants in the overweight group showed improvement during service $(\mathrm{p}<0.0001)$. A total of $74.4 \%$ of participants who were underweight and $82.2 \%$ of participants with obesity before military service showed improvements and attained normal weights during service $(p<0.0001)$ (Table 4$)$. Changes in body weight according to military characteristics were also observed (online supplementary appendix A-C).

The OR for an improved BMI in the subjective good health group compared with the subjective poor health group was statistically significant $(\mathrm{OR}=1.71,95 \% \mathrm{CI} 1.02$ to 2.87$)$. The OR for an improved BMI was significantly higher in the group with three or more times per week of strength training than in the group with one to two times per week of strength training and was higher among the marines compared with the Army soldiers $(\mathrm{OR}=1.48,95 \% \mathrm{CI} 1.03$ to 2.12 and $\mathrm{OR}=2.15,95 \%$ CI 1.07 to 4.32 , respectively) (Table 5).

\section{DISCUSSION}

This study investigated changes in BMI among enlisted men before and during military service and showed that the pattern of change was an improvement in health status. Our results revealed that $74.4 \%$ of soldiers who were underweight (BMI $<18.5 \mathrm{~kg} /$ $\mathrm{m}^{2}$ ) before military service improved to normal weight, with an average BMI increase of $5.87 \mathrm{~kg} / \mathrm{m}^{2}$, whereas $82.2 \%$ of those who were overweight (BMI $>25 \mathrm{~kg} / \mathrm{m}^{2}$ ) before service improved to normal weight, with an average BMI decrease of $5.47 \mathrm{~kg} / \mathrm{m}^{2}$ (Tables 3 and 4). These findings are consistent with the results of a previous study on changes in BMI before and during military service $^{20}$ and a previous study on BMI according to military service area (geographical area). ${ }^{33}$ Positive effects on BMI are expected as a result of regular diet and exercise characteristic of military life.

When we investigated factors including the general and military characteristics of the participants, we found that age, subjective health status, strength exercise and military variables were all significantly associated with improvements in BMI (Table 5). Enlisted men aged 20-21 years were more likely to show improvements in BMI than those aged over 21 years. These results are consistent with those of previous studies involving adolescents and adults, which showed that excess weight increases with age. ${ }^{26} 34$ In contrast, another study analysing changes in obesity status among enlisted soldiers before and during military service ${ }^{20}$ showed that BMI in older age groups decreased during military service.

BMI was more likely to improve in participants who perceived their health status as good than in those who perceived their health status as poor. This result is consistent with the results of a previous study in adults. ${ }^{35}$ BMI of those who performed strength training three or more times per week was more likely to improve than those who performed strength training one to two times per week. The analysis of the changes in BMI with respect to participants' general characteristics also showed that strength training was a variable exhibiting significant differences between the groups (Table 1). Performing strength training had significant effects on both changes in BMI and improvements in weight. Therefore, further studies that can reflect changing exercise trends while measuring strength exercise as a key variable of physical activity are required.

Among the military forces (Army, Navy, Marine Corps and Air Force), the proportion of participants who improved to normal weight from overweight before military service was highest in the marines, and the proportion of those who deteriorated to overweight or underweight from normal weight before service was lowest also in the marines (online supplementary appendix $\mathrm{B}, \mathrm{C})$. Our analysis showed that the marines were significantly 
Table 5 Factors associated with improvements in BMI during military service according to general and military characteristics

\begin{tabular}{|c|c|c|}
\hline & \multicolumn{2}{|c|}{ Improvement group } \\
\hline & $\mathrm{OR}^{*}$ & $95 \% \mathrm{Cl}$ \\
\hline \multicolumn{3}{|l|}{ Age (years) } \\
\hline$<20$ & 1.20 & 0.50 to 2.87 \\
\hline $20-21$ & 1.48 & 1.01 to 2.17 \\
\hline$\geq 22$ & Ref & \\
\hline \multicolumn{3}{|l|}{ Educational level } \\
\hline High school & Ref & \\
\hline College or above & 1.32 & 0.89 to 1.96 \\
\hline \multicolumn{3}{|l|}{ Smoking status } \\
\hline Non-smoker & Ref & \\
\hline Ex-smoker & 1.14 & 0.66 to 1.98 \\
\hline Current smoker & 1.14 & 0.83 to 1.56 \\
\hline \multicolumn{3}{|l|}{ Subjective health status } \\
\hline Good & 1.71 & 1.02 to 2.87 \\
\hline Normal & 1.32 & 0.79 to 2.22 \\
\hline Poor & Ref & \\
\hline \multicolumn{3}{|l|}{ Physical activity (MET-min/week) } \\
\hline$<600$ & Ref & \\
\hline $600-3000$ & 0.95 & 0.63 to 1.44 \\
\hline$>3000$ & 0.96 & 0.64 to 1.44 \\
\hline \multicolumn{3}{|l|}{ Strength training } \\
\hline None & 1.21 & 0.80 to 1.81 \\
\hline 1-2 times per week & Ref & \\
\hline$\geq 3$ times per week & 1.48 & 1.03 to 2.12 \\
\hline \multicolumn{3}{|l|}{ Sleep duration (hours/day) } \\
\hline$<6$ & 0.67 & 0.25 to 1.76 \\
\hline $6-7$ & Ref & \\
\hline$\geq 8$ & 1.03 & 0.75 to 1.41 \\
\hline \multicolumn{3}{|l|}{ Sleep disturbance } \\
\hline No & Ref & \\
\hline Yes & 0.86 & 0.55 to 1.36 \\
\hline \multicolumn{3}{|l|}{ Military } \\
\hline Army & Ref & \\
\hline Navy & 1.40 & 0.86 to 2.27 \\
\hline Marine Corps & 2.15 & 1.07 to 4.32 \\
\hline Air Force & 1.12 & 0.68 to 1.86 \\
\hline \multicolumn{3}{|l|}{ Branches } \\
\hline Combat & Ref & \\
\hline Technical & 1.06 & 0.70 to 1.61 \\
\hline Administrative/special & 1.19 & 0.67 to 2.11 \\
\hline \multicolumn{3}{|l|}{ Service period (months) } \\
\hline$<6$ & Ref & \\
\hline $6-11$ & 0.89 & 0.57 to 1.40 \\
\hline $12-17$ & 0.82 & 0.53 to 1.26 \\
\hline$\geq 18$ & 0.94 & 0.54 to 1.64 \\
\hline \multicolumn{3}{|l|}{ Type of workplace } \\
\hline Large, middle and small cities & Ref & \\
\hline Country, town, township & 1.02 & 0.69 to 1.49 \\
\hline Remote areas & 0.78 & 0.43 to 1.39 \\
\hline \multicolumn{3}{|l|}{ Working hours (hours/day) } \\
\hline$<40$ & 1.14 & 0.76 to 1.72 \\
\hline $40-55$ & Ref & \\
\hline$\geq 56$ & 1.24 & 0.88 to 1.75 \\
\hline
\end{tabular}

${ }^{*}$ Regression analysis was performed using the deterioration group as the reference (ref) group. Stress and depression variables were excluded from the table because they did not show significant results during the analysis.

BMI, body mass index; MET, metabolic equivalent of task. more likely to show improvements in BMI than the Army soldiers, who showed consistent results.

This study has limitations. First, we did not investigate eating habits, a major contributor to obesity. In the military, enlisted men are supposed to eat at designated times following a planned diet of $3300 \mathrm{kcal}$ per day, which means that eating habits in the military are more controlled than among civilians. However, differences may still occur in individuals' meal sizes and snack intake. Second, the Military Health Survey used in this study was conducted among enlisted men during service. Therefore, if the general characteristics of the survey participants changed during their military service, for example, if sleep duration was shorter than before service, the data collected would not reflect such changes. Third, military service can lead participants to change many aspects of their lifestyle, such as smoking, physical activity and sleep, from their lifestyle before service. Fourth, these results may not be generalisable to non-conscripted Armed Forces as our population only consisted of enlisted Armed Forces. Any generalisations to other Armed Forces which rely on volunteers who arrive fitter than the conscripted are not recommended in similar studies associated with BMI. Further studies are required with regard to changes in health behaviour before and during military service. These could build on the Military Health Survey, which is conducted at the time of enlistment and which could help overcome the limitations of previous cross-sectional studies that have relied on recollections of concerned participants.

This study also has strengths. To our knowledge, it is the first to investigate BMI among enlisted men using a representative sample from the Army, Navy, Marine Corps and Air Force. Moreover, we identified changes in individual participants' BMI by merging the Military Health Survey data with participants' Military Entrance Physical Examination data. In addition, this study not only analysed changes in BMI in terms of gain and loss but also determined whether the pattern of such changes led to an improvement in health. Lastly, a military health survey is conducted among current officers and soldiers from July to August. To compare the parameters before and during military service of 1972 participants enrolled in the study, we matched the before military service data with the physical examination data collected on the day of enlistment. This made it possible to control for the time between enlistment and survey completion, resulting in a better understanding of the intensity and duration of the training received.

The results show that the majority of participants with abnormal weight, either overweight or underweight, improved to normal weight. Future research is required to analyse the differences in military obesity management programmes among the Army, Navy, Air Force and Marine Corps and to develop standardised health promotion programmes.

\section{CONCLUSIONS}

In our investigation, strength training showed a statistically significant increase in BMI during military service. Furthermore, BMI in men who were underweight before their service increased, whereas BMI in those who were overweight decreased. This pattern indicates that BMI returns to normal ranges during military life.

Contributors BNL, SWB, SYO, JHY, JR and JUW conceived and planned the study BNL, SWB, SYO and JHY performed the analysis. BNL, SWB and SYO wrote the original draft with input from all authors. BNL, SWB and JHY visualised the results. SYO, JR and JUW validated the study. BNL, SWB, SYO and JUW contributed to the interpretation of the results. JUW supervised the entire process. All of the authors read and approved the final manuscript. 
Funding The authors have not declared a specific grant for this research from any funding agency in the public, commercial or not-for-profit sectors.

Competing interests None declared.

Patient consent for publication Not required.

Ethics approval The study was approved by the institutional review board of the Armed Forces Medical Command (AFMC-15060-IRB-15-049).

Provenance and peer review Not commissioned; externally peer reviewed.

Data availability statement No data are available.

Open access This is an open access article distributed in accordance with the Creative Commons Attribution Non Commercial (CC BY-NC 4.0) license, which permits others to distribute, remix, adapt, build upon this work non-commercially, and license their derivative works on different terms, provided the original work is properly cited, appropriate credit is given, any changes made indicated, and the use is non-commercial. See: http://creativecommons.org/licenses/by-nc/4.0/.

ORCID iD

SW Bae http://orcid.org/0000-0002-2250-9604

\section{REFERENCES}

1 Abarca-Gómez L, Abdeen ZA, Hamid ZA, et al. Worldwide trends in body-mass index, underweight, overweight, and obesity from 1975 to 2016: a pooled analysis of 2416 population-based measurement studies in 128.9 million children, adolescents, and adults. The Lancet 2017;390:2627-42.

2 Nuttall FQ. Body mass index: obesity, BMI, and health: a critical review. Nutr Today 2015;50:117.

3 Mokdad AH, Ford ES, Bowman BA, et al. Prevalence of obesity, diabetes, and obesityrelated health risk factors, 2001. JAMA 2003;289:76-9

4 Matsuzawa Y, Funahashi T, Nakamura T. The concept of metabolic syndrome: contribution of visceral fat accumulation and its molecular mechanism. J Atheroscler Thromb 2011;18:629-39.

5 Lemon SC, Rosal MC, Zapka J, et al. Contributions of weight perceptions to weight loss attempts: differences by body mass index and gender. Body Image 2009;6:90-6.

6 Kopelman P. Health risks associated with overweight and obesity. Obes Rev 2007:8 Suppl 1:13-17.

7 Bae KK, Kim H, Cho SI. Trends in body mass index and associations with physical activity among career soldiers in South Korea. J Prev Med Public Health 2011:44:167-75.

$8 \mathrm{Ng} \mathrm{M}$, Fleming T, Robinson M, et al. Global, regional, and national prevalence of overweight and obesity in children and adults during 1980-2013: a systematic analysis for the global burden of disease study 2013. The Lancet 2014;384:766-81.

9 Adderley-Kelly B. The prevalence of overweight and obesity among undergraduate health sciences students. Abnf J 2007:18:46-50

10 Yoon K-H, Lee J-H, Kim J-W, et al. Epidemic obesity and type 2 diabetes in Asia. Lancet 2006:368:1681-8.

11 Park HS, Park CY, Oh SW, et al. Prevalence of obesity and metabolic syndrome in Korean adults. Obes Rev 2008:9:104-7.

12 Kim DM, Ahn CW, Nam SY. Prevalence of obesity in Korea. Obes Rev 2005;6:117-21.

13 Khang Y-H, Yun S-C. Trends in general and abdominal obesity among Korean adults: findings from 1998, 2001, 2005, and 2007 Korea National health and nutrition examination surveys. J Korean Med Sci 2010;25:1582-8.

14 Yoo S, Cho H-J, Khang Y-H. General and abdominal obesity in South Korea, 19982007: gender and socioeconomic differences. Prev Med 2010;51:460-5.
15 Oh SW, Shin S-A, Yun YH, et al. Cut-Off point of BMI and obesity-related comorbidities and mortality in middle-aged Koreans. Obes Res 2004;12:2031-40.

16 Seo MH, Lee W-Y, Kim SS, et al. Korean Society for the study of obesity guideline for the management of obesity in Korea. Journal of obesity \& metabolic syndrome 2018;2019:40-5

17 Bae NK, Kwon IS, Cho YC. Ten year change of body mass index in Korean: 1997 2007. Korean J Obes 2009;18:24-30.

18 Korea Ministry of Government Legislation. The military service law. Available: https:// www.lawnb.com/Info/ContentView?sid=L000001622 [Accessed September 5 2019].

19 Nam J-W, Ha JH, Choi E, et al. Mature defense mechanisms affect successful adjustment in young Adulthood-Adjustment to military service in South Korea. Psychiatry Investig 2019;16:484-90.

20 Lee $\mathrm{H}$-J. Influence on enlisted soldiers' health behavior, Body-shape perception, and weight control toward the BMI change. J Korea Academia-Industrial Cooperation Soc 2015;16:3353-60.

21 Reynolds K, Cosio-Lima L, Bovill M, et al. A comparison of injuries, limited-duty days, and injury risk factors in infantry, artillery, construction Engineers, and special forces soldiers. Mil Med 2009;174:702-8.

22 Timlin MT, Pereira MA, Story M, et al. Breakfast eating and weight change in a 5-year prospective analysis of adolescents: project eat (eating among teens). Pediatrics 2008; 121:e638-45.

23 Pednekar MS, Gupta PC, Shukla HC, et al. Association between tobacco use and body mass index in urban Indian population: implications for public health in India. BMC Public Health 2006;6:70.

24 Hasler G, Buysse DJ, Klaghofer R, et al. The association between short sleep duration and obesity in young adults: a 13-year prospective study. Sleep 2004;27:661-6.

25 Dragan A, Akhtar-Danesh N. Relation between body mass index and depression: a structural equation modeling approach. BMC Med Res Methodol 2007;7:17.

26 Gallagher D, Visser M, Sepúlveda D, et al. How useful is body mass index for comparison of body fatness across age, sex, and ethnic groups? Am J Epidemiol 1996;143:228-39.

$27 \mathrm{Kim} \mathrm{TK}$, Jeon B-C, Bae E, et al. Association between personal protective equipment use and injury occurrence among the Republic of Korea armed forces. Mil Med 2017;182:e1900-7.

28 Kim TK, Lee H-C, Lee SG, et al. The combined effect of sleep duration and quality on mental health among Republic of Korea armed forces. Mil Med 2016;181:e1581-9.

29 Kim TK, Lee SG, Han K-T, et al. The association between perceived unmet medical need and mental health among the Republic of Korea armed forces. J R Army Med Corps 2017:163:184-92.

30 Kim TK, Lee H-C, Lee SG, et al. The influence of sexual harassment on mental health among female military personnel of the Republic of Korea armed forces. J R Army Med Corps 2017;163:104-10.

31 Kim Y-H, Nam G-E, Cho K-H, et al. Low bone mineral density is associated with dyslipidemia in South Korean men: The 2008-2010 Korean National Health and Nutrition Examination Survey. Endocr I 2013;60:1179-89

32 JY O, Yang YJ, Kim BS, et al. Validity and reliability of Korean version of international physical activity questionnaire (IPAQ) short form. J Korean Academy Family Med 2007:28:532-41.

33 Voss JD, Allison DB, Webber BJ, et al. Lower obesity rate during residence at high altitude among a military population with frequent migration: a Quasi experimental model for investigating spatial causation. PLoS One 2014;9:e93493.

34 Jee Y-J, Kim Y-H. Factors influencing obesity among adolescent: analysis of 2011 Korean youth risk behavior survey. Korean J Obes 2013;22:39-49.

35 Jaworowska A, Bazylak G. An outbreak of body weight dissatisfaction associated with self-perceived BMI and dieting among female pharmacy students. Biomed Pharmacother 2009;63:679-92. 